\title{
ALGUNOS ASPECTOS PROBLEMÁTICOS DE LA RESPONSABILIDAD CIVIL DE LOS ABOGADOS EN DERECHO ESPAÑOL*
}

\author{
María Carmen Crespo Mora"
}

\section{RESUMEN}

Pese a que, durante mucho tiempo, los profesionales liberales gozaron de cierta inmunidad, recientemente existen abundantes sentencias en las que se declara la responsabilidad civil de los abogados, que demuestran que han dejado de ser intocables. Aunque son muchas las cuestiones analizadas en este artículo, destaca el estudio detallado de los daños que puede provocar el abogado negligente y, en concreto, el daño denominado por la doctrina como "pérdida de la chance". Las páginas siguientes se dedican precisamente al estudio de esta compleja cuestión.

Palabras clave: abogados, negligencia profesional, responsabilidad civil, daño, pérdida de la oportunidad.

\section{AbStRact}

In spite of the long period of time in which liberal professionals were protected by certain immunity, recently there have been numerous judicial decisions, which allowing that lawyer's civil responsibility, evidence that lawyers are no longer untouchable. Although we mention many analytical aspects in this article, the detailed study of the damages that the negligent lawyer can provoke stands out in the analysis. More precisely, we focus

* El presente trabajo constituye una síntesis de parte de la tesis doctoral titulada $L a$ responsabilidad del abogado en el Derecho civil, Navarra, Ed. Thomson-Civitas, 2005, que obtuvo el VII premio Francisco de Asís Sancho Rebullida, a la mejor tesis de Derecho Civil defendida en su curso académico en las universidades españolas.

** Licenciada y doctora en Derecho Privado, Social y Económico por la Universidad Autónoma de Madrid. Profesora de Derecho Civil de la Universidad Carlos III de Madrid. Correo electrónico: carmen.crespo@uam.es y mccrespo@der-pr.uc3m.es. Artículo recibido el 11 de marzo de 2009 y aceptado el 7 de abril de 2009. 
on the type of damage known as "loss of a chance". The following pages are focused on the study of this complex matter.

Key words: lawyers, professional negligence, liability, damage, loss of a chance.

\section{EsTADO ACTUAL DE LA CUESTIÓN}

Hasta no hace mucho tiempo todos los profesionales liberales eran admirados y venerados por los ciudadanos. Si tras someterse a una operación quirúrgica el paciente fallecía, siempre se acudía al destino o a la providencia para explicar este fatídico final. Los daños eran considerados castigos divinos, y ante esta situación, a los ciudadanos sólo les quedaba una alternativa posible: la resignación. Sin embargo, en los últimos tiempos, la actitud de los ciudadanos frente a los daños que sufren ha experimentado un importante cambio. La resignación de antaño ha dado paso a una búsqueda del culpable a quien demandar y exigir la reparación de los daños sufridos. Para conseguir este objetivo, se ha utilizado de forma indiscriminada la institución de la responsabilidad civil, olvidando, con ello, que la respon-

102 sabilidad, lejos de ser la norma constituye la excepción, pues la misma no ha sido concebida como una vía ordinaria de satisfacción frente a cualquier revés de la vida ${ }^{1}$.

Así, pues, los profesionales liberales han pasado de ser intocables, a destinatarios de infinidad de demandas de responsabilidad civil. Sin embargo, este proceso ha sido gradual. De hecho, en un principio, el mencionado fenómeno afectó tan solo a determinados profesionales; a los médicos primero y a los arquitectos, después. Pero durante décadas, los abogados continuaron gozando de la inexplicable inmunidad que les protegía ${ }^{2}$. Prueba de ello es que, hasta 1995, no existe una sentencia del Tribunal Supremo español que declare de forma expresa la responsabilidad civil de estos profesionales del Derecho $^{3}$. Evidentemente, la ausencia de sentencias al respecto, hasta esta

${ }^{1}$ En palabras de Rafael Álvarez Vigaray, "La responsabilidad por daño moral”, en Anuario de Derecho civil, vol. 19, No 1, Madrid, 1966, p. 104, "son muchos los sufrimientos que las personas se causan unas a otras y que deben permanecer jurídicamente irrelevantes".

${ }^{2}$ Recientemente, constatan esta realidad María Ángeles PARra LuCÁn y Luis Fernando, Reglero Campos, "La responsabilidad civil de los profesionales del Derecho", en Luis Fernando Reglero Campos (coord.), Tratado de responsabilidad civil, $4^{\mathrm{a}}$ ed., Navarra, Ed. Thomson-Aranzadi, 2008, tomo II, p. 819.

${ }^{3}$ El Tribunal Supremo español estima por primera vez una demanda de reclamación de daños interpuesta contra un abogado por su cliente, en la sentencia del Tribunal Supremo de 17 de noviembre de 1995. En este caso, se declara la responsabilidad del abogado por 
fecha, no significa que, con anterioridad, los abogados hubieran sido siempre diligentes. Lo que realmente ocurría es que, cuando el cliente descubría que había sufrido la negligencia de su letrado, la compañía aseguradora de la responsabilidad civil del profesional se encargaba de arreglar la cuestión mediante un acuerdo económico que, al venir auspiciado por la aseguradora del abogado incumplidor, resultaba poco ventajoso para el cliente ${ }^{4}$.

La ausencia de sentencias estimatorias que se produce en un primer momento resulta, en cierto modo, inexplicable, pues los especiales conocimientos científico-jurídicos de los tribunales deberían facilitar la apreciación de los requisitos de la responsabilidad civil de los abogados. A fin de cuentas, a diferencia de lo que sucede con el resto de profesionales liberales, el análisis de la responsabilidad no exige recurrir a la ayuda de los peritos; es decir, el juez puede, por sí mismo, sin necesidad de ayuda pericial, comprobar si se cumplen los requisitos de la responsabilidad.

La explicación a esta situación de inmunidad probablemente haya de situarse en cierto corporativismo mal entendido (pues al cliente perjudicado no le resulta fácil encontrar a un abogado dispuesto a plantear la correspondiente acción de responsabilidad contra un colega), como en la condición de profano del cliente que contrata los servicios del letrado, lo que le impide descubrir que el daño que ha experimentado se debe al comportamiento negligente del profesional. De hecho, la jurisprudencia española está plagada de negligencias flagrantes y evidentes de los abogados, que, no obstante, pasaron inadvertidas para sus clientes. En palabras del profesor Mariano Yzquierdo Tolsada, si los clientes supieran por qué los abogados a veces pierden los pleitos "tal vez habría tantas sentencias de responsabilidad civil de abogados como las hay de médicos" 5 .

Además de las razones anteriores, la escasez de sentencias sobre el tema hasta hace unos años se explica igualmente por las dificultades que plantea

no instar en el Registro de la Propiedad la prórroga de la anotación preventiva de un embargo trabado sobre ciertas fincas; ello provoca la caducidad de la anotación practicada, permitiendo así a la contraparte (el dueño de las fincas) transmitir libremente los bienes a un tercero de buena fe, cuya adquisición -inscrita en el Registro de la Propiedad- resulta finalmente protegida. Con anterioridad, las demandas de responsabilidad civil del abogado fueron desestimadas por el Alto Tribunal (ello sucede, entre otras, en las sentencias del Tribunal Supremo de 20 de octubre de 1989, 5 de abril de 1990, 4 de febrero y 23 de diciembre de 1992 y 23 de octubre de 1995).

${ }^{4}$ De hecho, según Antonio Albanés Membrillo, "La responsabilidad civil del abogado: quantum indemnizatorio. Comentario a la STS de 28 de enero de 1998", en revista Otrosí. net, Madrid, mayo 1998, p. 7, tras estas negociaciones, los clientes del letrado obtenían como indemnización, a lo sumo, los gastos que les había ocasionado el proceso frustrado por su impericia.

${ }^{5}$ Véase, "Comentario a la STS de 10 de octubre de 1998", en Cuadernos Civitas de Jurisprudencia Civil, No 50, Madrid, Civitas, abril-agosto 1999, marginal 1354, p. 542. 
el propio EGAE (principal norma corporativa reguladora de la profesión), que obliga a todo abogado, antes de interponer cualquier tipo de acción contra un colega, a informar previamente de ello al colegio profesional y solicitar la oportuna mediación del decano ${ }^{6}$.

Por otra parte, el tipo de daños que se produce en estos casos -muchas veces de carácter puramente económico-justifica, en cierto modo, el que las negligencias de los abogados, ni llamen la atención de la opinión pública ni preocupen tanto a la doctrina como la impericia de otros profesionales.

Pues bien, el cliente que descubre que los daños que ha sufrido derivan del incumplimiento del letrado y que encuentra a otro abogado dispuesto a interponer las acciones necesarias para exigir la reparación, todavía tendrá que probar los presupuestos de la responsabilidad civil para conseguir que este profesional resulte responsable civilmente. Como la obligación que normalmente compromete al jurista frente al cliente es de medios ${ }^{7}$ y no de resultado, sólo podrá hablarse de responsabilidad si en el desarrollo de su cometido el letrado no desplegó la diligencia y habilidad técnica exigible al profesional de su condición, y ello tiene como consecuencia un daño o perjuicio para la persona que contrató sus servicios que, además, ha de encontrarse conectado causalmente a la actividad dañosa del profesional. 104 Así, de acuerdo con las normas procesales españolas (concretamente, el artículo 217 Ley de Enjuiciamiento Civil) corresponderá al actor (en nuestro caso, el cliente) probar los hechos constitutivos de su pretensión: esto es, el incumplimiento del abogado, su falta de diligencia, el daño sufrido y

${ }^{6}$ De esta forma, el artículo 79 del Estatuto General de la Abogacía Española (real decreto 658/2001, de 22 de junio) dispone expresamente: "el abogado que reciba el encargo de promover actuaciones de cualquier clase contra otro sobre responsabilidades relacionadas con el ejercicio profesional, deberá informar al Decano del Colegio para que pueda realizar una labor de mediación, si la considera oportuna, aun cuando el incumplimiento de dicho deber no pueda ser disciplinariamente sancionado".

${ }^{7}$ Véase, en tal sentido, la sentencia del Tribunal Supremo de 14 de diciembre de 2005 , según la cual, "el contrato de prestación de servicios (...) en el caso del abogado se concreta en llevar la dirección de un proceso, que es una actividad de medios, no de resultado, pues no se obliga a que tenga éxito la acción ejercitada sino a ejercitar ésta de conformidad con lo pactado y por las normas previstas reglamentariamente (...)". Ello no impide, no obstante, que la realización de determinados actos procesales que impone la llevanza de un proceso en la vía jurisdiccional, puedan ser considerados concretos deberes de resultado (v.gr., redacción y presentación de la demanda o cualquier otro escrito o recurso). Así lo reconocen, Mariano YzQuierdo Tolsada, "Responsabilidad civil del abogado", en La Universidad y las profesiones jurídicas (Deontología, función social y responsabilidad), ciclo de conferencias, Madrid, Universidad Complutense de Madrid, Consejo Social, 1998, p. 66, Adela Serra Rodríguez, La responsabilidad civil del abogado, Navarra, Ed. Aranzadi, 2001, p. 199 y Parra Lucán y Reglero Campos (n. 2), p. 826. 
la correspondiente relación de causalidad ${ }^{8}$. Sin embargo, la acreditación del nexo causal así como la determinación del daño y la valoración del quantum indemnizatorio, son cuestiones que entrañan una gran dificultad probatoria. Tales dificultades disminuyen si lo comprometido es un resultado y no se produce (v.gr., el abogado no concluye un dictamen en el tiempo fijado), pues, en tal caso, corresponderá al profesional la prueba de que la inejecución es debida a una causa extraña a él no imputable. En definitiva, en la mayoría de las ocasiones recaerá sobre la parte más débil, el cliente, la carga de la prueba con todos los inconvenientes que ello conlleva. Por ello, precisamente, la doctrina afirma que la prueba de tales extremos puede llegar a convertirse en una prueba diabólica para el cliente $y$, en consecuencia, en otro obstáculo a la exigencia de responsabilidad de los profesionales del Derecho.

En cualquier caso, pese al tímido reconocimiento de que fue objeto la responsabilidad de estos profesionales en un primer momento, la más reciente jurisprudencia del Tribunal Supremo español constituye una prueba manifiesta de la superación de esta reticencia inicial, pues cada vez son más numerosas las sentencias que reconocen la responsabilidad de estos profesionales. Ahora bien, el dato que realmente nos permite pronosticar la segura consolidación del fenómeno en el ordenamiento español es el elevado número de sentencias dictadas últimamente por los tribunales inferiores, en especial por las diferentes audiencias provinciales. Todo ello ha llevado a algunos autores a afirmar -en mi opinión, de forma un tanto desproporcionada-, que "se ha abierto la veda para la caza del abogado".

$\mathrm{Al}$ incremento considerable de sentencias sobre el tema hay que sumar el cambio cualitativo que está experimentando la jurisprudencia. Así, aunque los primeros errores de abogados que llamaron la atención de los tribunales españoles fueron los relativos a incumplimientos de plazos previstos en las normas procesales ${ }^{10}$, en los últimos tiempos el reconocimiento

${ }^{8}$ Por consiguiente, "en los supuestos de responsabilidad por infracción de deberes profesionales no es de generalizada aplicación la inversión de la carga de la prueba" (sentencia del Tribunal Supremo de 23 de diciembre de 1992), por lo que, recaerá "por supuesto en el cliente demandante la carga de probar, tanto la existencia de un daño indemnizable (...), como la falta de diligencia del letrado y, finalmente, el vínculo causal entre aquel menoscabo y el comportamiento negligente, contrario a los deberes profesionales" (STS de 21 de junio de 2007).

${ }^{9}$ Albanés Membrillo (n. 4), p. 8.

${ }^{10}$ La misma evolución jurisprudencial puede constatarse en el Derecho Comparado. Por ejemplo, Marie-Annick PEAno, "Avocat", en Juris-Classeur civil, No 32, fasc. 330, arts. 1382 à 1386, Quebec, s/a, p. 4, admite que, en la jurisprudencia francesa, muchas de las sentencias sobre responsabilidad de abogados derivan igualmente de la no interposición en plazo de una acción. Por lo que respecta al Derecho español, declaran la responsabilidad del letrado por dejar transcurrir plazos sustantivos o procesales, las siguientes sentencias: 
de responsabilidad de los abogados deriva del incumplimiento de ciertos deberes accesorios que habitualmente acompañan a la prestación principal. En concreto, son ya numerosas las sentencias que declaran la responsabilidad del letrado por omitir información al cliente ${ }^{11}$, por revelar el secreto confiado por él mismo ${ }^{12}$ o por perder los documentos que le habían sido entregados al inicio de la relación contractual ${ }^{13}$. Incluso, existen sentencias que hacen lo responsable de los daños que desencadena el irrazonable planteamiento técnico del asunto ${ }^{14}$; ahora bien, en estos últimos casos, el abogado sólo es declarado responsable civilmente si ha incurrido en un error patente, indubitado e incontestable. En otras palabras, los tribunales

sentencias del Tribunal Supremo de 16 de diciembre de 1996, 28 de enero, 25 de junio y 3 de octubre de 1998, 8, 14 y 28 de julio de 2003, 9 de julio de 2004 y 21 de junio de 2007.

${ }^{11}$ Un ejemplo paradigmático de la omisión del deber de informar lo constituye la importante sentencia del Tribunal Supremo de 14 de mayo de 1999. En este caso, como consecuencia del fallecimiento de un menor en una piscina municipal, se sigue causa penal que termina con auto de sobreseimiento. Tras el mencionado auto, el abogado que defendía los intereses de los padres del menor se limita a enviar una carta a sus clientes, notificándoles el sobreseimiento y aconsejándoles no recurrirlo, sin informarles acerca de las posibles acciones ante la vía civil. Cuando los padres se personan ante el abogado, ya había prescrito la correspondiente acción de daños y perjuicios. Pues bien, el Tribunal Supremo reconoce 106 que el letrado "no debió haberse limitado a aconsejar que no merecería la pena recurrir el auto de sobreseimiento de las referidas actuaciones penales, en cuanto que en buena técnica jurídica y en cumplimiento del deber de confianza que en él habían depositado sus clientes y a tenor de la diligencia correspondiente al buen padre de familia del artículo 1104 del $C C$, tendría que haber extendido el consejo a las posibilidades de defensa de una reclamación en el orden civil por culpa contractual o extracontractual, y a la conveniencia de mantener una entrevista inmediata con el matrimonio para explicarles con detalle el alcance y significado de tales posibilidades, proceder el así indicado que, indudablemente, se habría acomodado al correcto y normal cumplimiento de las obligaciones deontológicas inherentes al ejercicio de la abogacía rectamente entendida, y sin que sea factible exculpar el proceder enjuiciado por las circunstancias de que los clientes no hubieran solicitado al señor letrado les informase acerca de otras posibilidades de satisfacer sus pretensiones (...)”. Otras sentencias en las que puede observarse el incumplimiento de este importante deber accesorio son, por ejemplo, las sentencias del Tribunal Supremo de 16 de diciembre de 1996, 25 de marzo de 1998, 14 de mayo de 1999, 8 de febrero de 2000 y 18 de febrero y 14 de diciembre de 2005 .

${ }_{12}$ Pese a que la obligación de guardar secreto es uno de los deberes de mayor tradición y desarrollo legislativo en el ordenamiento jurídico español, existen muy pocas sentencias que declaren la responsabilidad de los abogados por el incumplimiento de este deber. Sobre el tema, cabe citar la sentencia del Tribunal Supremo (sala de lo contencioso-administrativo) de 13 de mayo de 1999.

${ }^{13}$ Sobre responsabilidad del abogado por la no devolución de la documentación entregada por el cliente, véase la sentencia del Tribunal Supremo de 25 de marzo de 1998.

${ }^{14}$ Se hace responder civilmente al letrado por desconocer la legislación o jurisprudencia aplicables al caso litigioso, entre otras, en las sentencias del Tribunal Supremo de 3 de octubre de 1998 y 8 de junio de 2000. 
españoles han pasado de valorar comportamientos u omisiones procesales que suponen un incumplimiento flagrante por parte del abogado, a enjuiciar hipótesis menos evidentes, pero constitutivas igualmente de inobservancia de la obligación.

En cualquier caso, independientemente del motivo desencadenante de la responsabilidad del letrado, debe descartarse de manera categórica que pueda servir de indicio de su responsabilidad civil la simple pérdida del pleito incoado por aquél ${ }^{15}$. Dicho de otra forma, aunque fracase el proceso, la responsabilidad civil del abogado sólo podrá afirmarse si concurren los requisitos de la misma; esto es, si el fracaso deriva de la defectuosa actuación o la omisión del jurista y ello provoca daños que se encuentran conectados causalmente a tal comportamiento. Lo contrario podría provocar el riesgo de extender de manera excesiva la responsabilidad de estos profesionales, pues, como en la mayoría de los procesos suele haber una pretensión que gana y otra que fracasa, potencialmente cabría imputar negligencia al cincuenta por ciento de los abogados (los que pierden), lo que resulta totalmente inadmisible.

$\mathrm{El}$ incremento exponencial de jurisprudencia sobre el tema que se ha producido en los últimos años ha ido acompañado, paralelamente, de una mayor atención por parte del legislador español, proceso que culmina con la promulgación del Código Penalde 1995. En el mencionado cuerpo legal se tipifican como delitos conductas que tradicionalmente habían sido reprimidas sólo en el plano deontológico o, a lo sumo, en el civil. Sirva como ejemplo el apartado segundo del artículo 467 del $C P$, que atribuye consecuencias penales a la acción u omisión del letrado que "perjudique de forma manifiesta los intereses que le fueron encomendados". La amplia formulación del mencionado precepto ha sido criticada por un sector de la doctrina penalista, ya que es previsible que en la práctica se planteen problemas para diferenciar las acciones u omisiones del abogado reprimibles exclusivamente en el plano deontológico o el civil, de aquellas otras que merezcan sanción penal $^{16}$. Ante las facilidades que ofrece el Código Penal puede pronosticarse, pues, un incremento de la jurisprudencia sobre el tema en esta jurisdicción debido a que, a través de la vía penal, el cliente perjudicado puede alcanzar un doble objetivo: la obtención de una indemnización (la denominada "responsabilidad civil derivada del delito") y la correspondiente inhabilita-

${ }^{15}$ De hecho, el Tribunal Supremo español ha reconocido expresamente, que el hecho de no haber tenido éxito judicial, no puede ser valorado como una presunción de culpabilidad (entre otras, sentencias del Tribunal Supremo de 3 de octubre de 1998, 8 de junio de 2000 y 30 de julio de 2007).

${ }^{16}$ Manuel Cancio Meliá, "Comentario al capítulo vil CP. De la obstrucción a la justicia y la deslealtad profesional: artículos 463, 465, 466 y 467”, en Gonzalo Rodríguez Mourullo (dir.), Jorge Barreiro (coord.), Comentarios al Código penal, Madrid, Editorial Civitas, 1997, p. 1.221 . 
ción especial para el ejercicio de la profesión (sanción penal prevista para la comisión por parte de los abogados de los delitos de "obstrucción a la justicia y deslealtad profesional"), a la que algunos denominan, de manera ciertamente desproporcionada, "la muerte civil" del letrado.

La anterior predicción se ha visto confirmada recientemente tanto por sentencias del Tribunal Supremo como de las diferentes audiencias provinciales, que sitúan bajo los amplios y difusos contornos del artículo 467.2 del $C P$ conductas que, hasta el momento, sólo habían provocado su responsabilidad civil: supuestos de preinscripción o caducidad de la acción que ha de interponer el profesional (STS -sala de lo penal- de 22 de mayo de 2002); la no personación ante la audiencia, a pesar de haber sido emplazado, dejando decaer la posibilidad de ejercer la acción penal y civil (SAP Castellón de 18 de noviembre de 2002); la retención de la documentación entregada para la realización de las gestiones encomendadas al abogado (SAP Vizcaya de 20 de diciembre de 2002); la inactividad del abogado en relación con la gestión encomendada (STS -sala de lo penal- de 5 de febrero de 2002, SAP Valencia de 1 de julio de 2002, SAP Castellón de 18 de julio de 2003 y SAP Toledo de 27 de diciembre de 2007), etcétera.

En el ámbito legislativo, otro importante paso en este proceso de exigencia de responsabilidad a los profesionales del Derecho lo constituye la 108 Ley 2/2007, de 15 de marzo, de Sociedades Profesionales, que trata de dar respuesta a los problemas de responsabilidad civil que surgen cuando el profesional liberal en general, y el abogado en particular, ejerce el oficio junto a otros profesionales en el seno de una sociedad profesional. Concretamente, la mencionada ley resuelve la cuestión de la responsabilidad civil en los despachos o bufetes de abogados que se constituyen como sociedades profesionales con la consiguiente inscripción en el Registro Mercantil. De esta forma, tras diferenciar la responsabilidad derivada de las deudas sociales (que sólo afectará a aquellos profesionales que reúnan la condición de socio y cuyo quantum dependerá del tipo de sociedad de que se trate), de la que desencadena la mala praxis, la ley (principalmente, el artículo 11) hace responsable del defectuoso, inexistente o inexacto cumplimiento de las obligaciones contractuales, de forma solidaria, tanto a los profesionales -socios o no- que hayan actuado -con independencia de la naturaleza del vínculo que les una a la sociedad profesional- como a esta última ${ }^{17}$. fesionales.

17 "Artículo 11: Responsabilidad patrimonial de la sociedad profesional y de los pro-

1. De las deudas sociales responderá la sociedad con todo su patrimonio. La responsabilidad de los socios se determinará de conformidad con las reglas de la forma social adoptada.

2. No obstante, de las deudas sociales que se deriven de los actos profesionales propiamente dichos responderán solidariamente la sociedad y los profesionales, socios 
Ello supone, pues, que, cuando el profesional del Derecho desempeñe su labor en el seno de un despacho profesional, en caso de negligencia con consecuencias dañosas, el cliente podrá dirigirse indistintamente contra cualquiera de los sujetos implicados (esto es, contra el concreto profesional del que deriva tal actuación negligente, contra cualquier otro profesional que haya participado en el asunto - v.gr., contra el director del equipo-, o contra el despacho colectivo) o contra todos ellos a la vez, y exigirles por entero el pago de la indemnización. La consagración de un régimen de responsabilidad en términos tan generosos supone, no obstante, la legalización de una práctica jurisprudencial constante y reiterada -aunque, todo sea dicho, contraria a la presunción legal de mancomunidad que rige en las obligaciones contractuales ex artículo 1137 del $C C^{18}-$ de nuestro Alto Tribunal, que antes de la promulgación de la citada ley ya apreciaba repetidamente la responsabilidad solidaria en casos como estos ${ }^{19}$.

Por otra parte, la citada ley impone a las sociedades profesionales la contratación de un seguro que cubra la responsabilidad civil derivada del ejercicio profesional. En definitiva, son tantas las medidas previstas en la Ley de Sociedades Profesionales a favor de los clientes que solicitan y contratan los servicios prestados a través de sociedades de abogados, que puede afirmarse que, en la actualidad, estas sociedades suponen una mayor garantía para el cliente, que el tradicional profesional aislado y particular o, en otras palabras, que el modo clásico de ejercer la profesión.

Como era de esperar, esta situación no ha dejado indiferentes a los colegios profesionales, que contemplan con lógico recelo este fenómeno que ya no tiene marcha atrás. Las citadas entidades encubren su malestar

o no, que hayan actuado, siéndoles de aplicación las reglas generales sobre la responsabilidad contractual o extracontractual que correspondan.

3. Las sociedades profesionales deberán estipular un seguro que cubra la responsabilidad en las que éstas puedan incurrir en el ejercicio de la actividad o actividades que constituyen el objeto social".

${ }^{18} \mathrm{El}$ tenor literal del mencionado precepto dispone: "la concurrencia de dos o más acreedores o dos o más deudores en una sola obligación no implica que cada uno de aquellos tenga derecho a pedir, ni cada uno de éstos deba prestar íntegramente, las cosas objeto de la misma. Sólo habrá lugar a esto cuando la obligación expresamente lo determine, constituyéndose con el carácter de solidaria”.

${ }^{19}$ Entre otras muchas, declaran la responsabilidad solidaria de los profesionales participantes en el proceso de edificación las sentencias del Tribunal Supremo de 6 de marzo de 1990, 21 de febrero de 2000, 18 de marzo de 2001, 13 de mayo de 2002, 27 de febrero de 2003, 10 de febrero y 29 de noviembre de 2004 y 24 de mayo de 2007. Las sentencias del Tribunal Supremo español de 12 de marzo y 4 de octubre de 2004, por su parte, declaran la responsabilidad solidaria del cirujano y del anestesista. En relación con los profesionales del Derecho, la sentencia del Tribunal Supremo de 18 de febrero de 2005 estima la responsabilidad solidaria del abogado y del procurador. 
bajo una aparente preocupación por los clientes que, según los mismos, serán los verdaderos perjudicados por este proceso a largo plazo, pues -argumentan los colegios profesionales-, serán quienes asuman los costos adicionales que éste implica. Así, para proteger su ejercicio profesional, los abogados contratarán seguros cuyo costo terminarán repercutiendo a sus clientes, a través de sus minutas. La existencia de tales seguros tendrá, además, un doble efecto pernicioso: por un lado, desincentivará de alguna forma la diligencia debida por parte del profesional, que probablemente conduzca su actuación bajo la idea de que el seguro es el que paga. Por otro lado, se corre el riesgo de que los jueces que conocen estos asuntos traten de favorecer a la víctima, bajo la idea de que la compañía aseguradora es quien va a asumir finalmente la carga de la reparación.

De igual forma, los colegios profesionales acusan a la responsabilidad profesional de ser paralizante para la actividad de los abogados, pues, debido a su amenaza, éstos procurarán no arriesgarse y defender únicamente pretensiones que presenten un alto porcentaje de prosperabilidad. Sin embargo, esta crítica carece de fundamento por dos razones básicamente. En primer lugar, los defensores de esta idea parecen partir de la hipótesis de que la pérdida de un litigio constituye un indicio claro de la responsabilidad civil del abogado que lleva el asunto, afirmación que ha de descartarse por 110 las razones expuestas anteriormente. En segundo lugar, si la pretensión que se presenta ante el letrado tiene escasas probabilidades de prosperar, para protegerse de futuras reclamaciones, lo único que tiene que hacer es informar de manera exhaustiva al cliente de los riesgos y las probabilidades de éxito. A mi juicio, la exigencia de responsabilidad civil, más que un lastre que paralice la actividad del abogado, contribuye firmemente a elevar el nivel del ejercicio profesional.

\section{LA PRESTACIÓN DE SERVICIOS DEL LETRADO: NATURALEZA JURÍDICA}

Puesto que en el ordenamiento jurídico español existen dos clases de responsabilidades que se encuentran reguladas por normas distintas -la contractual y la extracontractual-, se impone la tarea de determinar el concreto tipo de responsabilidad que entra en juego en estos $\operatorname{casos}^{20}$. Aun-

${ }^{20}$ Pese a que la práctica de nuestros tribunales se ha encargado de difuminar las diferencias subsistentes entre estos dos tipos de responsabilidades, la existencia de un diferente plazo de prescripción para su exigencia (de un año para la responsabilidad extracontractual, ex artículo 1968.2 del $C C$, y de quince para la contractual, ex artículo 1964 del $C C$ ) hace que la presente cuestión tenga importantes consecuencias jurídicas en la práctica. Para analizar con detenimiento las diferencias entre ambas responsabilidades, véase Santiago CAVANILLAS 
que el ejercicio de la abogacía suscita numerosas hipótesis (entre otras, la prestación del abogado de oficio, los servicios jurídicos del abogado en el seno de un sindicato, de una empresa, etc.), frente al cliente o persona cuyos intereses defiende el letrado, la responsabilidad será generalmente de carácter contractual, al encontrarse ambas partes vinculadas por un contrato $^{21}$. Por ello, para poder afirmar el inexistente, inexacto o defectuoso cumplimiento del contrato desencadenante de la correspondiente responsabilidad contractual, habrá que calificar previamente la relación establecida entre ambos. Ahora bien, como los abogados pueden llegar a comprometer actividades de muy diversa índole, la definitiva calificación del vínculo contractual existente dependerá de la prestación principal que, en cada caso, se comprometa frente al cliente.

Pues bien, por lo que se refiere a la actividad típica, no única, encomendada a los abogados (la defensa en vía jurisdiccional de determinados intereses particulares) la jurisprudencia española actual, sin excepciones, propone su inclusión dentro de los márgenes del arrendamiento de servicios, regulado en los artículos 1583 a 1587 del $C C$ español ${ }^{22}$. Sin embargo, tras un análisis de los preceptos que el Código Civil español dedica a este contrato, puede comprobarse que el citado régimen contractual adolece de importantes defectos y carencias.

En primer lugar, el contrato de arrendamiento de servicios previsto en nuestro Código parece destinado únicamente a los servicios prestados en régimen de dependencia. Prueba de ello es el título de la sección en la que se enumeran los preceptos relativos a este arrendamiento ("Del servicio de criados y trabajadores asalariados”). Así, aunque en los últimos tiempos cada vez resulta más frecuente la prestación de servicios jurídicos por cuenta ajena

MúGICA, Isabel TAPIA FERNÁNDEZ La concurrencia de responsabilidad contractual y extracontractual. Tratamiento sustantivo y procesal, Madrid, Centro de Estudios Ramón Areces, 1992, pp. 1957 y José María MiQuel GonZÁlez, "La responsabilidad contractual y extracontractual: distinción y consecuencias", en Responsabilidad Civil, Cuadernos de Derecho Judicial, N $^{\circ} 19$, Madrid, 1993, pp. 61-78.

${ }^{21}$ Evidentemente, si la pretensión indemnizatoria proviene de un tercero ajeno, la responsabilidad deberá considerarse de naturaleza extracontractual, aunque tal hipótesis es infrecuente en la práctica de nuestros tribunales. De hecho, hasta la fecha, la sentencia del Tribunal Supremo de 26 de septiembre de 1989, es la única sentencia del Alto Tribunal que conoce una demanda de responsabilidad civil interpuesta por un tercero contra el abogado de la parte contraria. Concretamente, en este caso, un deudor demanda por la vía que ofrece el artículo 1902 del $C C$ al abogado de su acreedor, por no haber evitado la continuación de un procedimiento ejecutivo. Tal pretensión es desestimada por faltar la antijuridicidad o ilicitud de la acción u omisión que se atribuye al letrado.

${ }^{22}$ Se pronuncian en tales términos, entre otras muchas, las sentencias del Tribunal Supremo de 12 y 30 de diciembre de 2003, 14 de julio de 2005, 11 y 23 de mayo de 2006 y 23 de marzo y 30 de julio de 2007. 
mediante un contrato de trabajo ${ }^{23}$, lo cierto es que el servicio prestado por los profesionales liberales es, por definición, independiente (en el sentido de que no se encuentra sometido a las directrices técnicas de un superior); por ello, precisamente, la actual normativa del arrendamiento de servicios no constituye un soporte adecuado para el trabajo independiente de estos profesionales.

En segundo lugar, los preceptos del Código Civil español sobre el citado arrendamiento no mencionan de forma expresa a los profesionales liberales, circunstancia que no puede atribuirse al despiste del legislador, ya que en otros preceptos del Código Civil dichos profesionales son citados expresamente. A lo anterior hay que añadir una crítica de estilo: la redacción de estos preceptos (que se refieren constantemente a "amos" y "criados") choca frontalmente con la sensibilidad de nuestra época.

Ahora bien, sin lugar a dudas, el mayor inconveniente que presenta la vigente regulación del contrato de arrendamiento de servicios es su extrema brevedad: casi todos los preceptos que nuestro Código Civil dedica a este contrato (tan sólo cinco artículos: del 1583 al 1587) han sido derogados tácitamente por la normativa laboral o por la Constitución española, de tal forma que la doctrina restringe la vigencia de esta sección a los artículos 1583 y 1587 del $C C$. Al igual que la doctrina, numerosas sentencias del Tribunal Supremo admiten que la mayoría de las normas reguladoras de este tipo contractual no se encuentran ya en vigor ${ }^{24}$. En definitiva, el ámbito de aplicación de estos preceptos se ha ido reduciendo a medida que se ha ido consolidando el Derecho del Trabajo; a pesar de ello, los preceptos relativos a este contrato no han sido objeto de reforma ni de derogación expresa. De hecho, la esperada reforma de este contrato constituye una de las reivindicaciones legislativas más antiguas de la doctrina civilista española. Tal reivindicación, además, no tiene alcance meramente teórico, habida cuenta la creciente importancia en nuestra sociedad de las profesiones liberales, principales destinatarias de este tipo contractual.

Puesto que la escueta y anticuada regulación del arrendamiento de servicios se muestra claramente insuficiente para organizar todo un régimen jurídico contractual, la doctrina española ha intentado reconstruir el exiguo régimen jurídico del citado arrendamiento, con normas distintas a las contenidas en los artículos 1583 a 1587 del $C C$. En concreto, se ha

${ }^{23}$ Pese a que, durante un tiempo, fue muy cuestionada doctrinal y jurisprudencialmente la prestación de servicios profesionales en régimen laboral, en la actualidad resulta indudable que la prestación de servicios de los abogados que trabajan en los bufetes puede realizarse a través de un contrato de trabajo, si bien tal relación laboral será de carácter especial, como expresamente reconoce el real decreto 1331/2006, de 17 de noviembre, por el que se regula la relación laboral de carácter especial de los abogados.

${ }^{24}$ En este sentido se pronuncian, entre muchas otras, las sentencias del Tribunal Supremo de 25 de marzo de 1998 y 23 de mayo de 2001. 
tratado de colmar las lagunas que presenta la regulación de este contrato a través de la normativa del mandato, el tipo contractual más próximo, pues tanto en el citado arrendamiento como en el mandato, el deudor se obliga a prestar un servicio (véase, en tal sentido, los artículos 1544 -arrendamiento de servicios- y 1709 -mandato-). Ahora bien, aunque ambos tipos normativos partan de un supuesto de hecho semejante, existe entre ellos ciertas diferencias insalvables ${ }^{25}$ que impiden la directa aplicación de la normativa del mandato, a los supuestos que tradicionalmente han sido considerados arrendamientos de servicios (por ejemplo, el contrato que regula la prestación de los profesionales liberales), como ha propuesto cierto sector de la doctrina civilista española ${ }^{26}$. Ello no significa que haya de rechazarse de manera categórica la aplicación de las normas del mandato en estos casos; a mi juicio, debe preferirse su aplicación analógica que exige, como se sabe, la identidad de razón entre la concreta norma reguladora del mandato y el supuesto de hecho no regulado por la escueta normativa del arrendamiento de servicios. Concretamente, desde mi punto de vista, deberán descartarse aquellas normas del mandato que, por partir de una prestación gratuita de los servicios profesionales, tratan de favorecer al mandatario que actúa de manera gratuita y desinteresada, pues resultan incompatibles con las prestaciones de los profesionales liberales, habitualmente onerosas.

Junto a las labores procesales, el letrado puede comprometer frente al cliente, como prestación principal, una labor extrajudicial. En tal caso, la gran variedad de actividades que puede asumir contractualmente le impide realizar una afirmación general sobre el contrato celebrado por las partes, por lo que la respuesta variará según lo que éstas hayan pretendido al contratar. De esta forma, si el cliente le solicita la elaboración de un dictamen sobre una cuestión jurídica controvertida o la redacción de cualquier otro documento (contratos, estatutos, etc.), la relación contractual deberá situarse bajo los márgenes del contrato de obra ${ }^{27}$. Si, por el contrario, se compro-

${ }^{25}$ La principal diferencia entre ambos regímenes contractuales es que, mientras el arrendamiento de servicios constituye un contrato esencialmente oneroso (artículo 1544 del $C C$ ), el contrato de mandato es naturalmente gratuito, esto es, se presume gratuito salvo prueba en contrario (artículo 1711 del CC). Ello explica que, determinados preceptos relativos al mandato (v.gr., artículos 1721, 1729, 1732 y 1736) traten de favorecer al mandatario, por presumir que éste desempeña su actividad sin recibir retribución alguna.

${ }^{26}$ Principalmente, María Teresa Alonso Pérez, Los contratos de servicios de abogados, médicos y arquitectos, Barcelona, Editorial Bosch, 1997, p. 162 y ss.; María Dolores Cervilla GARZón, La prestación de servicios profesionales, Valencia, Editorial Tirant lo Blanch, 2001, p. 93 y Alma Rodríguez Guitián, La muerte del oferente como causa de extinción de la oferta contractual, Madrid, Editorial Civitas, 2003, p. 98.

${ }^{27}$ La jurisprudencia, unánimemente, considera que la elaboración de un dictamen constituye un arrendamiento de obra: sentencias del Tribunal Supremo de 4 de febrero de 1950, 28 de noviembre de 1984, 3 de octubre de 1998 y 23 de mayo de 2001. 
mete a la gestión de asuntos del cliente frente a terceros, no hay duda de que volveremos a estar en presencia de una obligación de medios. Más controvertido resulta, no obstante, la determinación del tipo contractual suscrito por las partes ${ }^{28}$, etcétera.

Ahora bien, cualquiera que sea el deber de prestación principal del abogado (actividad judicial o extrajudicial), la adecuada ejecución del mismo exigirá el cumplimiento de otros deberes accesorios ${ }^{29}$. El problema es que, en la práctica, estas prestaciones no suelen encontrarse expresamente contempladas en el contrato de servicios concertado con el profesional. Al tratarse de deberes que no se encuentran de forma expresa previstos en el contrato, la doctrina española se ha cuestionado el carácter contractual o extracontractual del daño que experimenta el cliente como consecuencia de su contravención. Pues bien, hay que señalar que este interrogante recibe distintas respuestas en la doctrina y jurisprudencia españolas. En incontables sentencias, el Alto Tribunal español encaja en el marco del artículo 1902 (precepto regulador de la responsabilidad extracontractual) el incumplimiento de deberes que no habían sido estipulados previamente por las partes, pero que implican una violación de imperativos legales o profesionales, por no encontrarse

${ }^{28}$ Aunque hay autores que se decantan por la existencia de un contrato de arrendamiento de servicios en estos casos (principalmente, Luis Martínez Calcerrada y Gómez, "La responsabilidad civil profesional del abogado", en Luis Martínez CALCERRAda y Gómez, La responsabilidad civil profesional de los teleinformáticos, auditores de cuentas, periodistas, arquitectosperitos, médicos-peritos y de los peritos judiciales en general. Especial estudio de la responsabilidad civil de los médicos, administradores, consejeros de las sociedades mercantiles y de los abogados, Madrid, Editorial Colex, 1991, p. 371, la sentencia del Tribunal Supremo de 25 de noviembre de 1999 afirma la existencia de mandato en un supuesto de este tipo.

${ }^{29}$ Los citados deberes se encuentran previstos únicamente en normas corporativas o deontológicas. Ante la ausencia de previsión legal al respecto, le ha correspondido al Tribunal Supremo español la enumeración de los principales deberes accesorios que se encuentran a cargo del abogado. Señala, al respecto, la sentencia del Tribunal Supremo de 21 de mayo de 2001: "por consiguiente, también en otra versión podían desmenuzarse todos aquellos deberes o comportamientos que integran esa prestación o en las respectivas conductas a que pueda dar lugar o motivar el ejercicio de esa prestación medial en pos a la cual, se afirma la responsabilidad; ad exemplum: informar de 'pros y contras', riesgo del asunto o conveniencia o no del acceso judicial, costos, brevedad de la situación, probabilidad de éxito o fracaso, lealtad y honestidad en el desempeño del encargo, respeto y observancia escrupulosa de las leyes procesales, y cómo no, aplicación al problema de los indispensables conocimientos de la Ley y del Derecho". De igual forma, señala la sentencia del Tribunal Supremo de 3 de octubre de 1998 que "a lo que está obligado el abogado es, pues, a prestar sus servicios profesionales con competencia y prontitud requeridas por las circunstancias de cada caso (artículo 1258 del $C$ C). En esa competencia se incluye el conocimiento de la legislación y jurisprudencia aplicable al caso, y a su aplicación con criterios de razonabilidad si hubiese interpretaciones no unívocas". 
dentro de la "órbita estricta de lo pactado" 30 . Sin embargo, la posición dominante en la doctrina es la contraria. Para la mayoría de nuestros autores, los deberes accesorios derivados de la buena fe o de los usos de los negocios son deberes contractuales, aunque no aparezcan reflejados en el contrato ${ }^{31}$. Tal solución deriva del artículo 1258 del $C C$, según el cual, los contratos obligan no sólo a lo expresamente pactado sino, también, a todas aquellas consecuencias que, de acuerdo con su naturaleza, deriven de la buena fe, los usos y la ley.

\section{DAÑOS ESPECÍfICOS DERIVADOS \\ DE LA ACTUACIÓN DEL ABOGADO}

La responsabilidad civil del abogado está, pues, a la orden del día. Ahora bien, pese a que los interrogantes jurídicos que suscita la responsabilidad civil de estos profesionales son numerosos, actualmente la cuestión más controvertida en esta materia es, sin lugar a dudas, la determinación del daño indemnizable y el cálculo de su quantum indemnizatorio ${ }^{32}$. Aunque en este ámbito han de aplicarse, en principio, las reglas generales del sistema - por constituir la responsabilidad del abogado un mero apartado en la disciplina general de la responsabilidad civil-, cuando se valora la responsabilidad de los abogados tales normas se muestran insuficientes. Esto es así porque, junto a daños fácilmente identificables y cuantificables -como, por ejemplo, los gastos o costas del proceso que se perdió por culpa del abogado $^{33}-$, el ejercicio de la abogacía puede desencadenar otros daños de carácter mucho más complejo y que no se producen en otros sectores de la responsabilidad civil. De hecho, la especialidad que puede llegar a revestir el daño derivado de la actuación u omisión del abogado es la

${ }^{30}$ Entre otras muchas, sentencias del Tribunal Supremo de 9 de marzo de 1983, 10 de mayo de 1984, 9 de enero de 1985 y 10 de junio de 1991 .

${ }^{31}$ Apuestan claramente por la responsabilidad contractual en estos casos, entre otros muchos, Fernando Pantaleón Prieto, "Comentario al artículo 1902 CC", en Comentarios del Código civil, Madrid, Ministerio de Justicia-Editorial Civitas, 1993, tomo II, p. 1.977, SERrA Rodríguez (n. 7), p. 159 y Luis Díez-Picazo, Derecho de daños, Madrid, Editorial Civitas, 2000, p. 265.

${ }^{32}$ En su reciente estudio, reconocen la complejidad que entrañan estas cuestiones PARRA Lucán y Reglero Campos (n. 2), p. 859.

${ }^{33}$ Pese a que, en un principio, el Tribunal Supremo español negó la indemnización de los gastos procesales derivados del proceso frustrado por la defectuosa actuación u omisión del abogado (por ejemplo, en la sentencia del Tribunal Supremo de 17 de noviembre de 1995), actualmente son numerosas las sentencias que condenan al abogado responsable civilmente al pago de estos gastos y costas procesales: v.gr., sentencias del Tribunal Supremo de 16 de diciembre de 1996, 11 de noviembre de 1997, 25 de junio de 1998 y 18 de junio de 2004. 
razón que justifica, precisamente, el estudio detallado de este elemento ${ }^{34}$. Por el contrario, el resto de los elementos de la responsabilidad de estos profesionales no presentan peculiaridades especiales que justifiquen un análisis pormenorizado de los mismos.

Llegados a este punto, he de advertir que, pese a que la actividad del letrado puede desarrollarse tanto en el ámbito judicial como en el extrajudicial, en esta exposición voy a centrarme en examinar únicamente ciertos daños que puede llegar a provocar su comportamiento negligente dentro del marco del proceso, por tratarse de la actividad típica encomendada a los abogados, y porque el incumplimiento de los plazos y normas procesales sigue siendo el principal comportamiento sobre el que giran la mayoría de las sentencias recaídas sobre el tema. Por tanto, el estudio de los daños se hace desde la perspectiva de los casos que se presentan con mayor frecuencia en la práctica judicial. Imaginemos, pues, que un profesional interpone la demanda o recurso de su cliente fuera de plazo. En supuestos como éste, ¿̇en qué consiste el daño?

Los daños que puede llegar a ocasionar la conducta descrita son muy variados. En primer lugar, en determinadas circunstancias, un estudio de la pretensión que ha resultado frustrada por la negligencia del letrado puede arrojar la conclusión de que, de no ser por la actuación del abogado, ésta 116 habría prosperado, esto es, tras el estudio del caso, se puede llegar a afirmar que si hubiera sido diligente se habría obtenido una sentencia estimatoria con toda seguridad o con una probabilidad rayana en la certeza ${ }^{35}$. En estos

${ }^{34}$ No sólo en la materia que nos ocupa el daño desempeña un papel fundamental; de todos los requisitos de la responsabilidad civil, ha sido considerado el más importante, por ser el que "pone en marcha el mecanismo de la responsabilidad civil y de la reparación". Elena Vicente Domingo, "El daño", en Luis Fernando Reglero Campos (coord.), Tratado de responsabilidad civil, $4^{\mathrm{a}}$ ed., Navarra, Editorial Thomson-Aranzadi, 2008, tomo I: Parte general, pp. 303-304; Mariano YzQuiERdo TOLSADA, Sistema de responsabilidad civil, contractual y extracontractual, Madrid, Editorial Dykinson, 2001, p. 143, admite también que el daño es "el elemento principal de la responsabilidad civil". Por su parte, en un caso de responsabilidad civil de letrados, afirma el Tribunal Supremo: "no toda declaración de culpabilidad conlleva la de responsabilidad, pues para ello es preciso que pueda anudarse a la actuación negligente del agente un daño susceptible de ser reparado, en su caso, mediante la correspondiente indemnización, de tal forma que, si falta éste, no cabe imponer indemnización alguna” (sentencia del Tribunal Supremo de 15 de noviembre de 2007).

${ }^{35}$ Esto es lo que sucede, por ejemplo, en la sentencia de la audiencia provincial de Málaga de 25 de abril de 2002. Según la misma, en el caso que resuelve "no estamos ante el albur del resultado siempre incierto de un litigio, sino ante un acuerdo de la actora con su empresa sobre su indemnización por despido, cuya improcedencia se había reconocido por la empresa en acto de conciliación, y que sólo precisaba para materializarse la oportuna demanda de la trabajadora, que se presentó extemporáneamente por culpa del error del abogado". Así pues, la segura prosperabilidad del litigio puede asegurarse en este caso, porque tan sólo se trataba de reclamar la cantidad aceptada en los acuerdos previos. 
casos no habrá duda, pues, de que ha privado a su cliente de la pretensión misma. En tales circunstancias existirá un auténtico daño emergente ("la privación de la pretensión”) y, en consecuencia, la indemnización de daños y perjuicios habrá de coincidir con el valor de la pretensión frustrada, en el caso de que ésta tenga contenido económico. Tratándose, por el contrario, de una pretensión de carácter extrapatrimonial (v.gr., reconocimiento de paternidad, acciones de separación y divorcio, etc.), la determinación de la indemnización derivada de la privación de la pretensión al cliente no resultará tan sencilla, suscitándose en este punto los mismos inconvenientes que plantea la determinación del quantum indemnizatorio del daño moral.

En el campo judicial, constituye un ejemplo claro de privación de la pretensión lo que determinados autores, utilizando una ingeniosa expresión, han denominado como "pretensiones mellizas" ${ }^{36}$ : cuando la acción frustrada del cliente es idéntica a otras acciones que se enjuician de manera separada y que terminan siendo estimadas por los órganos de la jurisdicción. Imagínese el siguiente caso: en un proceso de expropiación que afecta a varias personas, todos impugnan en la vía administrativa el justiprecio fijado; sin embargo, por culpa del abogado, una de las reclamaciones no se presenta a tiempo mientras que el resto termina prosperando ${ }^{37}$. En esta hipótesis la determinación del quantum indemnizatorio resultará fácil, pues la pretensión perdida tiene contenido económico: la indemnización deberá coincidir con el valor cuantitativo de la pretensión. No obstante, en un principio, los tribunales españoles se mostraron un poco reacios a conceder como indemnización el valor económico de la pretensión frustrada por culpa del abogado, aunque pudiera vaticinarse a priori o a posteriori la estimación indubitada de la misma. Esto sucedió, por ejemplo, en una sentencia del Tribunal Supremo de 1996 (STS de 16 de diciembre de 1996), en que, pese a reconocer que "las posibilidades de éxito de la demanda en reclamación de aquellos daños y perjuicios por la muerte del causante de los actores eran ciertas", el Tribunal Supremo niega que la indemnización pueda consistir "en lo que los actores hubieran podido percibir como indemnización de los daños y perjuicios derivados del fallecimiento". Es decir, la citada sentencia reconoce veladamente que la actuación del abogado ha provocado la privación de la pretensión, pero, a pesar de ello, no concede como indemnización el valor

${ }^{36}$ Utilizan tal calificación J. González-Ferrer y J. YBARra López-Gómez, "La indefensión ocasionada por error del abogado", en Otrosínet, No 37, Madrid, mayo 2002, pp. 37-38.

${ }^{37}$ En la "jurisprudencia menor" de las audiencias provinciales también se pueden encontrar ejemplos de este tipo de pretensiones: v.gr., sentencia de la audiencia provincial de Cáceres de 7 de abril de 2000, en la que se admite que "las posibilidades de éxito vienen avaladas por el hecho de que el resto de los compañeros despedidos confían la defensa a distintos profesionales y todos ellos obtienen resoluciones judiciales favorables". 
de la misma ${ }^{38}$. Sin embargo, sobre este extremo también puede observarse una evolución en la jurisprudencia del Alto Tribunal español, ya que, en sus sentencias más recientes, admite abiertamente que la cuantía de la indemnización puede llegar a coincidir con el valor económico de la pretensión reclamada y, finalmente, frustrada por la impericia del letrado ${ }^{39}$.

Ahora bien, hay que reconocer que, por regla general, la privación de la pretensión no constituirá un daño automático en los casos de responsabilidad civil del abogado, debido a su carácter hipotético o eventual ${ }^{40}$. Ello es debido a que no siempre se puede asegurar que se ha perdido la pretensión. Cuando, por ejemplo, el abogado formaliza la demanda o recurso fuera del plazo previsto legalmente, en la mayoría de las ocasiones resultará imposible afirmar, sin lugar a dudas, el éxito de la acción no interpuesta $\mathrm{o}$, lo que es lo mismo, la estimación de la pretensión judicial del cliente. Por tanto, normalmente, la privación de la pretensión será un daño que difícilmente pueda concurrir, ya que, para ello, el porcentaje de prosperabilidad de la pretensión fallida habrá de ser del cien por ciento. Desde el momento en que disminuya tal porcentaje, no se puede entender que la conducta del letrado provoque la privación de la pretensión que tiene o cree tener el cliente. Determinado el carácter hipotético de este daño, no será necesario realizar más averiguaciones para negar la indemnización del mismo, por faltar el elemento desencadenante de la responsabilidad

${ }^{38}$ De igual forma, niega indirectamente que la cuantía de la indemnización pueda coincidir con la cuantía de la pretensión, pese a reconocer que el letrado ha hecho perder al cliente su pretensión, entre otras, la sentencia del Tribunal Supremo de 16 de diciembre de 2001 (sala de lo penal).

${ }^{39}$ Sentencias del Tribunal Supremo de 17 de noviembre de 1995, 3 de octubre de 1998, 18 de febrero de 2005 y 30 de julio de 2007. De entre estas sentencias, merece ser destacada la sentencia del Tribunal Supremo de 18 de febrero de 2005. En este caso, el abogado omite advertir al cliente sobre el plazo en el que ha de pagar el precio aplazado, provocando, por su impago en plazo, la resolución de la venta y la consiguiente pérdida del inmueble. Demostrada la inexistencia de conocimiento por parte del cliente, el abogado es condenado a pagarle una indemnización por el valor de mercado del piso, menos la actualización proporcional del precio aplazado.

${ }^{40}$ Ponen de relieve el carácter eventual de este daño Martínez Calcerrada y Gómez (n. 28), p. 369, Rodrigo Bercovitz Rodríguez-Cano, "Responsabilidad de abogados y procuradores", en Aranzadi Civil, No 3, Navarra, 1997, p. 20, Ángel V. Illescas Rus, "El daño moral estricto", en VV.AA., Valoración judicial de los daños y perjuicios, Madrid, Consejo General Poder Judicial, 1999, p. 255 y María Dolores Cervilla Garzón, "Una nueva visión de la responsabilidad profesional del abogado", en Actualidad Civil, No 40, Madrid, semana del 27 de octubre al 2 de noviembre de 2003, p. 1085.

Los tribunales españoles coinciden con la doctrina en este extremo. Así, entre otras, las sentencias del Tribunal Supremo de 23 de mayo de 2001 y 12 de diciembre de 2003 afirman que, por regla general, el daño no equivale "a la no obtención del resultado de la pretensión confiada o reclamación judicial (...) eventos de futuro (...) por su devenir aleatorio”. 
civil. En tales casos, su deficiente actuación podrá originar, a lo sumo, la privación a los clientes de unas expectativas o esperanzas procesales; esto es, en la mayoría de las ocasiones de lo que realmente se priva a la víctima es de la oportunidad de conseguir una sentencia estimatoria y no de la sentencia estimatoria como tal.

Pues bien, este perjuicio ha sido calificado por la doctrina con el galicismo "pérdida de una chance" ${ }^{41}$, categoría general de daños en la que se incluyen todos aquellos casos en los que el agente dañante, con su actuación u omisión, ha interrumpido un proceso con el que la víctima tenía probabilidades de conseguir una ganancia o evitar una pérdida, por encontrarse en la situación idónea para ello. Aunque la doctrina francesa ha propuesto diferentes ejemplos de pérdida de la chance -v.gr., el manuscrito que, contando con probabilidades de obtener un premio literario, no se imprime a tiempo por culpa del editor-, el ejemplo más significativo de pérdida de una chance lo constituye, sin lugar a dudas, la hipótesis de la que partimos en la presente exposición: un procurador o abogado encargado de interponer una demanda o recurso, deja transcurrir los plazos previstos por la ley para ello ${ }^{42}$.

En los ejemplos anteriores, ya no podrá saberse si el escritor hubiese obtenido el premio literario o si el abogado, de haber sido diligente, hubiera ganado o no el pleito. En ninguno de ellos puede afirmarse rotundamente que se habría alcanzado el resultado perseguido, aunque no cabe duda de que la víctima se encontraba en la posición idónea para conseguirlo. Por ello, de lo que realmente se le priva es de las esperanzas; de la probabilidad de conseguir ese resultado favorable. Y privar de esa esperanza al sujeto implica un daño, aunque la valoración del mismo resulte, como luego se demostrará, sumamente complicada. El daño consiste en la pérdida de la oportunidad de conseguir un beneficio, no en la pérdida del beneficio como tal: en el caso que nos ocupa, en la pérdida definitiva de la posibilidad de que la pretensión sea estimada por los tribunales.

Entonces, para que el daño por pérdida de oportunidad procesal resulte indemnizable, será necesario que reúna ciertos requisitos que han sido

${ }^{41} \mathrm{El}$ empleo de este galicismo es debido a que la teoría de la perte d'une chance es una creación de la doctrina y jurisprudencias francesas. No obstante, el perjuicio consistente en la pérdida de la chance no aparece reconocido por ningún texto legislativo específico en Derecho francés.

${ }^{42}$ Henri Mazeaud - André Tunc, Tratado teórico y práctico de responsabilidad civil delictual y contractual, traducción de la quinta edición por Niceto Alcalá-Zamora y Castillo, Buenos Aires, Ediciones Jurídicas Europa-América, 1961-1963, tomo I, vol. I, pp. 308-312. La pérdida de la oportunidad procesal, además de ser el ejemplo más significativo de pérdida de la chance, es el primer caso que se reconoce por los tribunales franceses. Así lo admite Yves Chartier, La réparation du préjudice, Paris, Ed. Dalloz, 1996, p. 15: "la plus traditionnelle, parce que la plus ancienne, est la perte d'une chance attachée à un droit”. 
apuntados y desarrollados por la doctrina y la jurisprudencia españolas. La mejor doctrina apunta que su indemnización ha de ser otorgada con cautela y de forma restrictiva, pues, de lo contrario, podría llegar a convertirse en un daño resarcible en cualquier hipótesis de responsabilidad civil. De hecho, en un principio, la doctrina francesa, la más proclive a conceder indemnizaciones por esta causa, negó la reparación de la pérdida de la chance, precisamente por las innumerables dudas que este daño provocaba, pues, según algunos autores, las oportunidades perdidas no dejaban de ser simples "castillos en el aire" ${ }^{43}$.

Los requisitos que han de concurrir para que reúna certeza y, en consecuencia, resulte indemnizable son básicamente dos: en primer lugar, que el resultado sea definitivo, esto es, que la situación no pueda ser solucionada a través de ulteriores actuaciones procesales; en otras palabras: si el cliente sigue contando con remedios procesales contra la sentencia desestimatoria, no se le podrá hacer responder al letrado por la pérdida de la oportunidad de que la pretensión fuese estimada por los órganos de la jurisdicción, puesto que el cliente seguirá contando con tal oportunidad ${ }^{44}$. Por tanto, la indemnización sólo resultará posible en los supuestos en los que la pretensión resulte desestimada de manera irrevocable y la sentencia goce de los efectos de la cosa juzgada. En segundo término, se requiere que, 120 antes de la defectuosa actuación u omisión del abogado, existiera alguna

${ }^{43}$ Pese a que, en un principio, la doctrina francesa discutió sobre si la pérdida de una oportunidad era o no merecedora de reparación, en la actualidad, es prácticamente unánime en afirmar que, a pesar de los inconvenientes existentes, la pérdida de la oportunidad es un daño susceptible de indemnización. En el Derecho alemán, por su parte, se niega el carácter de daño indemnizable de la pérdida de la oportunidad. El Derecho anglosajón se coloca en una posición intermedia. Por último, aunque la doctrina y jurisprudencia italianas se mostraron en un principio reacias a admitir la indemnizabilidad de la pérdida de la chance, a partir de los años ochenta se admite, aunque con muchas restricciones, el carácter resarcible de este daño. Para un análisis comparativo sobre la admisibilidad doctrinal y jurisprudencial de esta teoría en los diferentes países europeos, véase Christoph MüLleR, "Schadenersatz für verlorene Chancen. Ei des Kolumbus oder Trojanisches Pferd?", in www.wenger-plattner.ch. visitada el 10 de marzo de 2009.

${ }^{44}$ Precisamente por esta circunstancia se niega que el daño consista en la pérdida de la oportunidad en las sentencias del Tribunal Supremo de 7 de diciembre de 1989 y 18 de junio de 2004. En la primera de las sentencias citadas, se niega este daño "al no producirse el resultado dañoso que el tan aludido demandante pretende deducir de situación de prescripción por falta de presentación de la demanda en tiempo, dado que esa prescripción no se ha producido, y en consecuencia se mantiene viva la posibilidad de ejercicio de la acción planteada”. En el caso resuelto por la sentencia del Tribunal Supremo de 18 de junio de 2004 no hubo tampoco daño por oportunidad procesal, puesto que, al haber sido apreciada la excepción de falta de legitimación activa por la sentencia de primera instancia $y$, en consecuencia, al no entrar ésta en el fondo del asunto, la comunidad de propietarios (demandante) podía formular de nuevo el recurso. 
oportunidad de que la pretensión fallida fuera estimada, lo que no sucederá, evidentemente, cuando la acción o derecho hubiera prescrito antes de contratarse sus servicios ${ }^{45}$, pero tampoco cuando se trate de pretensiones totalmente infundadas o carentes de base jurídica ${ }^{46}$.

Cumplidas estas premisas, el mayor o menor porcentaje de prosperabilidad de la pretensión, si tal porcentaje pudiera calcularse, influirá sobre la indemnización que ha de percibir el cliente, sin que una menor seriedad o probabilidad de la oportunidad pueda llegar a convertirla en un daño eventual y, consecuentemente, no indemnizable, como sostienen algunos autores influidos probablemente por la doctrina italiana, que se muestra excesivamente restrictiva a la hora de estimar el daño por pérdida de oportunidad ${ }^{47}$. Basta, pues, que exista una oportunidad real para que su pérdida sea considerada daño cierto; cumplido este requisito, la pérdida de la oportunidad resultará indemnizable con independencia del porcentaje de prosperabilidad de la pretensión. En definitiva, las escasas probabilidades de vencer no han de repercutir en la certeza del daño, como sostienen algunos, sino únicamente sobre la cuantía de la indemnización que recibirá el cliente ${ }^{48}$. Si la oportunidad procesal perdida reúne los requisitos enumerados, al cliente le será reparado este perjuicio, siempre, claro está, que concurran el resto de requisitos de la responsabilidad civil.

Llegados a este punto, vuelven a suscitarse dudas en relación con el requisito del nexo de causalidad que ha de existir entre este daño especí-

${ }^{45}$ Ello sucede, por ejemplo, en el caso resuelto por la sentencia del Tribunal Supremo de 2 de diciembre de 2003: clientes que comunican a su abogado su decisión de interponer recurso contencioso-administrativo cuando ya había finalizado el plazo.

${ }^{46}$ Reconocen que la pérdida de la oportunidad deberá indemnizarse "salvo en el caso límite de que la probabilidad de éxito de la pretensión fuera cero", entre otras, las sentencias del Tribunal Supremo de 26 de enero de 1999, 28 de julio de 2003, 27 de julio de 2006 y 15 de noviembre de 2007; también, las sentencias de las audiencias provinciales de Huesca de 4 de diciembre de 1993 y de Badajoz de 3 de septiembre de 1996. Concretamente, en el caso resuelto por la sentencia del Tribunal Supremo de 28 de julio de 2003, un indicio determinante para llegar a la conclusión de que el proceso frustrado, de haber sido correctamente interpuesto, tampoco habría prosperado es que "consta la declaración de no haber lugar al recurso de casación núm. 1626/1995 recaído para un proceso sensiblemente, por no decir absolutamente igual al en que se suscitó la incidencia del recurso desierto, dando lugar a este juicio de responsabilidad civil del procurador negligente".

${ }^{47}$ Por ejemplo, según Francesco dE FAzio, "Responsabilitá del legale e perdita della chance di vincere il proceso", in Responsabilitá Civile e Previdenza, vol. 62, settembre-dicembre 1997, pp. 1.178-1.180, la pretensión ha de tener una probabilidad de hacerse efectiva superior al cincuenta por ciento. De igual forma, en la doctrina española, SERRA Rodríguez (n. 7), p. 246, señala que sólo pueden considerarse oportunidades perdidas efectivas y serias, las probabilidades con un porcentaje igual o superior al cincuenta por ciento.

${ }^{48}$ Crespo Mora (n. *), p. 378. 
fico y el comportamiento negligente u omisivo del letrado. Sin embargo, a mi juicio, en estos casos la relación de causalidad no plantea problemas diferentes a los de cualquier otro supuesto de responsabilidad civil ${ }^{49}$. Desde mi punto de vista, los autores que cuestionan la presencia de este elemento de la responsabilidad civil cuando se enjuicia la actividad del profesional parten de un daño equivocado: pretenden establecer un enlace con la privación de una sentencia favorable a los intereses del cliente, o lo que es lo mismo, la privación de la pretensión que éste poseía o creía poseer. Sin embargo, en realidad, el nexo de causalidad debe ser establecido, como ya se ha dicho, entre el hecho o la omisión del abogado y la pérdida de la oportunidad de que la pretensión sea estimada; no entre ese hecho o esa omisión y el daño consistente en la no obtención de la pretensión. En definitiva, el curso causal no se ha de establecer respecto del resultado que no se sabe si se habría producido de ser diligente el letrado, sino respecto del simple hecho de haber perdido la oportunidad de obtenerlo.

Dejando a un lado el problema de la posible naturaleza patrimonial o moral del daño consistente en la pérdida de la oportunidad procesal -tema debatido hasta la saciedad por la doctrina española_ ${ }^{50}$, la interrogante más importante que plantea esta clase de daños es la determinación cuantitativa de su indemnización. En otras palabras, ċqué indemnización merece quien se ha visto privado de una expectativa procesal?, ¿qué criterios ha

${ }^{49}$ Así lo reconoce Larroumet, Christian, Droit civil, Les obligations, 6 a ed., Paris, Economica, 2007, tome III, seconde partie, según el cual, "la perte d'une chance ne pose pas de probléme de causalité".

${ }^{50}$ Se muestran partidarios del carácter moral del daño consistente en la pérdida de la oportunidad, tanto diversas sentencias (entre otras, las sentencias del Tribunal Supremo de 28 de enero, 25 de junio y 3 de octubre de 1998, 14 de mayo de 1999, 29 de mayo de 2003, etc.), como diversos autores: Mariano YzQuierdo Tolsada, "Comentario a la STS de 28 de enero de 1998", en Cuadernos Civitas de Jurisprudencia Civil, No 47, Madrid, abril-agosto 1998, p. 680 y Martínez Calcerrada y Gómez (n. 7), p. 370. Se posicionan en contra del carácter moral de este daño, entre otros, PARra Lucán y Reglero Campos (n. 2), p. 865. Recientemente, la sentencia del Tribunal Supremo de 27 de julio de 2006 afirma el carácter patrimonial de este daño "si el objeto de la acción frustrada, como sucede en la mayoría de las ocasiones, y, desde luego, en el caso enjuiciado, tiene como finalidad la obtención de una ventaja de contenido económico mediante el reconocimiento de un derecho o la anulación de una obligación de esta naturaleza”. En idéntico sentido se pronuncia, posteriormente, la sentencia del Tribunal Supremo de 15 de noviembre de 2007.

Pese a que la determinación de la naturaleza jurídica del daño consistente en la pérdida de la oportunidad procesal es uno de los temas más estudiados y debatidos por la doctrina, hay que reconocer la importancia relativa de esta cuestión. La calificación de un determinado daño como patrimonial o moral no provoca consecuencias prácticas diferentes en Derecho español, pues ambos tipos de daños son resarcibles en los ámbitos contractual y extracontractual. Esto quizá explique el que la doctrina gala, a la que se debe el origen y desarrollo de esta teoría, apenas se haya pronunciado sobre este extremo. 
de tener en cuenta el juzgador, a la hora de calcular la indemnización correspondiente por este daño? Un parámetro importante para concretar la indemnización de la pérdida de la oportunidad es, fundamentalmente, el cálculo aproximado de las probabilidades de éxito o fracaso de la pretensión perdida ${ }^{51}$. Ello significa que la indemnización deberá ser más o menos elevada en atención a la mayor o menor probabilidad de éxito que tuviera la demanda o el recurso intempestivo. Sin embargo, el cálculo del porcentaje de probabilidad dista mucho de ser una cuestión sencilla ${ }^{52}$. Por ello, la doctrina sugiere dos procedimientos diferentes para efectuar tal cálculo.

En primer lugar, se señala el procedimiento estadístico; esto es, analizar el porcentaje de éxito de las reclamaciones de naturaleza análoga a la frustrada por el letrado. Cuanto mayor sea el porcentaje de éxito de estas reclamaciones, mayor deberá ser la reparación. Ahora bien, aunque esta técnica de valoración aporta certeza y seguridad jurídica, las limitaciones derivadas de este procedimiento son evidentes, pues resulta sumamente complicado encontrar supuestos de hecho idénticos y cualquier variación de los hechos entre dos casos, por mínima que sea, puede dar lugar a resultados jurídicos distintos. Por otra parte, tampoco hay que olvidar la existencia de una copiosa jurisprudencia del Tribunal Constitucional español, sobre la no vinculación de los órganos judiciales a los precedentes.

Por ello, ante los inconvenientes que plantea el procedimiento estadístico, el segundo criterio utilizado por la doctrina para concretar la indemnización por pérdida de oportunidad procesal es el denominado "juicio dentro del juicio". Este método consiste en un juicio imaginario a través del cual el juez que examina la responsabilidad del profesional determina hipotéticamente cuál habría sido el desenlace del asunto frustrado si la demanda o recurso se hubiese interpuesto a tiempo ${ }^{53}$. Sin embargo,

${ }^{51}$ Los Principios de Unidroit de 1994 parecen decantarse claramente por esta opción. En concreto, el artículo 7.4.3 (2) dispone: "la perte d'une chance peut être réparée dans la mesure de la probabilité de sa réalisation", en www.unidroit.org. visitada el 10 de marzo de 2009.

${ }^{52}$ En cualquier caso, el cálculo de la pérdida de oportunidades en materia procesal plantea menos inconvenientes que, por ejemplo, la pérdida de oportunidades en materia de responsabilidad médica, puesto que en estos otros ámbitos los tribunales han de recurrir a la ayuda de expertos para poder efectuar este cálculo. En esta materia, como ya he señalado, los tribunales son por sí mismos expertos en Derecho, por lo que no requieren el peritaje.

${ }^{53} \mathrm{La}$ primera sentencia que recurre a este procedimiento para cuantificar este tipo de daños es la sentencia del Tribunal Supremo de 20 de mayo de 1996. Posteriormente, el Tribunal Supremo español utiliza este recurso, entre otras, en las sentencias de 16 de diciembre de 1996 y 29 de mayo de 2003. Sin embargo, existen también sentencias que rechazan este método. Sirva como ejemplo, la sentencia del Tribunal Supremo de 11 de noviembre de 1997, al declarar que "resulta totalmente imposible saber, sin introducirnos en el resbaladizo y absolutamente inadmisible terreno de las conjeturas, cuál hubiera podido 
resulta complicado determinar qué resultado se pretende alcanzar con este método: si el juez ha de limitarse a indicar, en atención a las circunstancias concurrentes, la estimación o desestimación de la pretensión frustrada o, por el contrario, si el órgano judicial debe concretar el porcentaje de prosperabilidad de tal pretensión. De la elección de una u otra opción puede depender la cuantía de la indemnización que ha de satisfacer el letrado. $\mathrm{Si}$ se opta por la primera de las posibilidades y el órgano judicial considera que la pretensión frustrada habría sido estimada, parece que el abogado deberá indemnizar lo que valga la pretensión. Por el contrario, si el órgano judicial que realiza el "juicio dentro del juicio" debe concretar, además, el porcentaje de prosperabilidad, tal porcentaje deberá reflejarse en el quantum indemnizatorio. Aunque el Tribunal Supremo español no se ha decantado claramente a favor de ninguna de estas dos opciones, a mi juicio, ha de ser preferida la segunda, pues permite graduar con más exactitud la cuantía de la indemnización, pese a las dificultades que puede acarrear el cálculo de porcentajes de prosperabilidad en una materia como el Derecho ${ }^{54}$. La primera de ellas, además, resulta incompatible con el propio concepto de pérdida de oportunidad, porque implica indemnizar por completo una pretensión cuyo porcentaje de prosperabilidad, por definición, ha de ser inferior al cien por cien (pues de lo contrario nos encontraríamos, en rea124 lidad, ante una privación de la pretensión) ${ }^{55}$.

La principal ventaja que proporciona el denominado "juicio dentro del juicio" es que se trata de un método objetivo para cuantificar el daño en estos casos y, en consecuencia, evita cálculos arbitrarios del mismo ${ }^{56}$. Sin embargo, a pesar de las ventajas que proporciona, este método ha

ser el tratamiento (estimatorio o desestimatorio) que habrían recibido los tres frustrados (...) recursos de apelación (...)”.

${ }^{54}$ Así, puede afirmarse que los conocimientos jurídicos, en la mayoría de las ocasiones, son relativos. Junto a extremos absolutamente válidos y ciertos sobre los que existe una doctrina y jurisprudencia clara y reiterada, coexisten numerosas cuestiones discutibles, susceptibles de diferente valoración o interpretación. De hecho, según Ricardo de ÁNGEL YÁGǘz, "Comentario al artículo 1902 CC", en Ignacio Sierra Gil de la Cuesta (coord.), Comentario del Código civil, Barcelona, Ed. Bosch, 2000, tomo 8 (arts. 1790 al 1902), p. 498: "en la materia que nos ocupa casi todo se halla en el mundo de lo opinable". Reconocen, igualmente, la complejidad del Derecho, entre otras, las sentencias de las Audiencias Provinciales de Valencia de 23 de abril de 1998 y de Asturias de 6 de mayo de 1998.

${ }^{55}$ La pérdida de oportunidades y la privación de la pretensión no solamente son daños diferentes sino, también, incompatibles. En tal sentido, CresPo Mora (n. 48), p. 383.

${ }^{56}$ De hecho, la sentencia del Tribunal Supremo de 29 de mayo de 2003, advierte de ciertos inconvenientes que se producirían de no utilizarse este criterio: "el juez deberá establecer una indemnización a favor del cliente basada en una muy subjetiva apreciación de lo que para éste ha supuesto verse privado de la posibilidad de éxito en un juicio no entablado o en un recurso no promovido". 
recibido diferentes críticas. Entre otros reproches, se afirma: "no son parte quienes habrían sido demandados en aquel juicio ante la jurisdicción (...), demandados que podrían oponer una serie de defensas o excepciones" ${ }^{57}$. Por ello, se dice que el "juicio dentro del juicio" sólo aporta una "revisión distorsionada por falta de alegaciones de las partes y de contradicción entre éstas" (STS de 26 de enero de 1999). Sin embargo, esta crítica ha de matizarse, puesto que, aún sin desconocer este inconveniente -pues el juez o tribunal encargado de realizar el juicio dentro del juicio no siempre contará con todo el elemento probatorio del que hubiera dispuesto el juez o tribunal inicialmente competente-, no se comprende por qué el mismo ha de favorecer precisamente al abogado negligente que ha provocado esa situación.

Más cuestionable aún resulta la crítica que acusa a este método de provocar cierta vulneración de la cosa juzgada. Según el principio de cosa juzgada, una sentencia firme es irrevocable e inmutable, por lo que no cabe que otro tribunal vuelva a conocer sobre aquello que fue objeto de la misma. Pues bien, alguna sentencia española (v.gr., STS de 26 de enero de 1999), reconoce expresamente:

"no puede ahora entrar a revisar el contenido de la sentencia laboral firme en los términos en que lo habría podido hacer el Tribunal $\mathrm{Su}$ premo, caso de que se hubiera sostenido el recurso (...) por respeto a la santidad de la cosa juzgada".

A pesar de la afirmación anterior, podemos aseverar, sin temor a equivocarnos, que la utilización del citado método no provoca la vulneración de este principio, pues, tras la realización de este juicio imaginario, no se modifica la situación jurídica declarada en la sentencia firme; de hecho, lo único que persigue el proceso de responsabilidad civil es reparar al cliente perjudicado por la negligencia del abogado, pero su pretensión frustrada o no incoada continuará en la misma situación. Esta circunstancia es precisamente la que justifica el que el cliente reciba una indemnización en estos casos.

Debe rechazarse igualmente la crítica que denuncia que la utilización del citado método para valorar las probabilidades de éxito de pretensiones no civiles (laborales, penales o administrativas) supondría realizar por parte del órgano judicial que examina la responsabilidad civil del letrado (órgano de la jurisdicción civil) un juicio de probabilidad sobre otra jurisdicción, lo que, según la sentencia de la audiencia provincial de León de 16 de diciembre de 1994 resulta "totalmente inadmisible". El rechazo de

${ }^{57}$ En tales términos se pronuncia la sentencia del Tribunal Superior de Justicia de Navarra de 9 de diciembre de 1997. 
esta crítica se apoya en el principio de unidad jurisdiccional consagrado en el artículo 117.5 de la $\mathrm{CE}^{58}$.

Además de calcular las probabilidades de éxito de la pretensión frustrada (a través de cualquiera de los dos métodos expuestos: el estadístico y el denominado "juicio dentro del juicio"), la concreta determinación del quantum indemnizatorio de la oportunidad procesal perdida, exigirá realizar una operación adicional: aplicar el porcentaje de probabilidad o prosperabilidad hallado a la cantidad solicitada en el proceso no incoado o frustrado por la impericia del abogado ${ }^{59}$. Ahora bien, aunque la utilización conjunta de estos dos criterios proporciona una fórmula objetiva para calcular la indemnización, la aplicación de tal fórmula no está exenta de dificultades en el ámbito del Derecho, donde el cálculo de porcentajes de prosperabilidad, de poder realizarse, será en muchos casos aproximado. Por otra parte, pese a que los parámetros anteriores facilitan, sin lugar a dudas, la cuantificación económica de la pérdida de la oportunidad, en ocasiones no resultarán eficaces, como sucede con las pretensiones extrapatrimoniales. En estos casos, pues, el cálculo de la indemnización deberá efectuarse en términos semejantes a la cuantificación del daño moral.

Para terminar con el estudio de los daños derivados de la impericia del letrado, hay que diferenciar la pérdida de la oportunidad de otro daño ligado 126 a la actividad procesal: la privación del derecho que ostenta cualquier ciudadano a que sus pretensiones sean conocidas por los tribunales. El mayor inconveniente que suscita este daño -además del recurrente problema de su naturaleza jurídica- vuelve a ser, de nuevo, la determinación de su cuantía, puesto que el derecho del que se ve privado el cliente no es susceptible de cuantificación económica. En mi opinión, el cálculo del quantum indemnizatorio por la privación de este derecho será mucho más dificultoso, incluso, que la determinación de la cifra en la que ha de ser indemnizada la pérdida de la oportunidad procesal, ya que no pueden ser aplicados en este caso los criterios que utilizan doctrina y jurisprudencia para calcular la indemnización de aquélla, al tratarse de un derecho no susceptible de cuantificación económica ${ }^{60}$.

${ }^{58}$ Dispone el artículo 117.5 de la CE: "el principio de unidad jurisdiccional es la base de la organización y funcionamiento de los tribunales".

${ }^{59}$ Fernando Gómez Pomar, "Pleitos tengas: pérdida de un litigio, responsabilidad del abogado y daño moral. Comentario a la STS de 8 de abril de 2003", en www.indret.com, julio 2003, p. 5 (según paginación pdf), propone la utilización conjunta de estos dos criterios para calcular la cuantía del valor esperado. La utilización conjunta de estos dos criterios ha sido acogida igualmente por los tribunales españoles: por ejemplo, en las sentencias del Tribunal Supremo de 16 de diciembre de 1996 y 26 de enero de 1999 y en las sentencias de las audiencias provinciales de Castellón de 9 de septiembre de 1998 y Las Palmas de 9 de marzo de 2004.

${ }^{60}$ Reconoce la dificultad de determinar la entidad y cuantía de este daño la sentencia de la Audiencia Provincial de Barcelona de 26 de junio de 2002. En el mismo sentido se pronuncia Carolina del Carmen Castillo Martínez, "La indemnización por daños y la 
Por ello, el quantumindemnizatorio por este concepto deberá ser calculado por el juez que conozca de la acción de reclamación de daños contra el abogado, atendiendo a criterios de proporcionalidad y de ponderación.

Por otra parte, este daño suele ser calificado erróneamente como una vulneración del derecho a la tutela judicial efectiva, que aparece consagrado en el artículo 24 de la $\mathrm{CE}^{61}$. Sin embargo, si el letrado interpone una demanda o recurso fuera de plazo, la resolución judicial de inadmisión que recaiga satisfará las exigencias del artículo 24 de la $\mathrm{CE}$, pues incluso en este caso se habrá obtenido una resolución de los tribunales fundada en Derecho. Además, como el artículo 24 de la CE reconoce expresamente el derecho "a obtener la tutela efectiva de los jueces y tribunales", no puede hablarse de violaciones de este derecho que procedan de la actuación de quienes, como los abogados, no están integrados en el poder judicial ${ }^{62}$.

Recapitulemos. Los daños específicos que derivan de la responsabilidad de estos profesionales del Derecho son, en primer lugar, la privación de la pretensión, cuando pueda pronosticarse, sin lugar a dudas, un porcentaje de prosperabilidad de la pretensión del cien por cien; en segundo término, la pérdida de la oportunidad procesal, cuando la oportunidad procesal perdida fuera seria y fundada, pero con un porcentaje de prosperabilidad por debajo de esa cantidad y, en tercer y último lugar, la privación del derecho a los recursos. Pues bien, hay que reconocer que, tras un análisis exhaustivo de la jurisprudencia del Tribunal Supremo, puede afirmarse que, el Alto Tribunal español tiende a mezclar y confundir estos daños ${ }^{63}$,

problemática de su cuantificación (cuestiones escogidas)", en Revista Actualidad Civil, $\mathrm{N}^{\mathrm{0}}$ 41, Madrid, semana del 3 al 5 de noviembre de 2003, p. 1.119, para quien "en tales supuestos la cuantificación de la indemnización resulta más difícil de justificar habida cuenta de que (...) la concreción del daño se desvincula por completo del resultado final cuya inicial previsión resultó alterada por la actuación negligente del letrado, desapareciendo entonces cualquier referencia a criterios valorativos de índole objetiva que resultan sustituidos por la actuación plenamente discrecional del Tribunal”.

${ }^{61}$ Señala el precepto citado: "Todas las personas tienen derecho a obtener la tutela efectiva de los jueces y tribunales en el ejercicio de sus derechos e intereses legítimos, sin que, en ningún caso, pueda producirse indefensión". Apuntan la posible vulneración del derecho a la tutela judicial efectiva del artículo 24 de la CE, entre otras, las sentencias del Tribunal Supremo de 28 de enero de 1998 y 7 de abril de 2003 y las sentencias de las audiencias provinciales de Álava de 15 de septiembre de 1992, Guipúzcoa de 12 de septiembre de 1994, Cantabria de 11 de febrero de 2003 y Toledo de 19 de enero de 2004.

${ }^{62}$ Concretamente, la sentencia del Tribunal Constitucional de 7 de febrero de 1984 afirma: "existen derechos que sólo se tienen frente a los poderes públicos (como los del artículo 24)".

${ }^{63}$ La confusión y mezcla de estos dos tipos de daños es constatada por CRESPO MORA, María Carmen, entre otras, en la sentencia de 29 de mayo de 2003 (véase "Responsabilidad civil del abogado. Especial referencia a la pérdida de la oportunidad procesal. Comentario a la STS de 29 de mayo de 2003”, en Revista de Derecho Patrimonial, N ${ }^{\circ} 12$, Navarra, 2003, 
denominando pérdida de oportunidad lo que, en realidad, constituye una mera vulneración del derecho a los recursos y viceversa; o, como ya se ha dicho, valorando la indemnización en una cantidad que no coincide con la cuantía de la pretensión reclamada y no obtenida por la impericia del letrado tras reconocer que, de no mediar la negligencia del mismo, aquélla hubiera sido obtenida con toda seguridad; o, simplemente, utilizando el fácil remedio de incluir estos daños "en el haz vaporoso de lo que la doctrina considera el daño moral" 64 , para evitarse así tanto la determinación de su carácter como la concreción de su cuantía.

Pese a lo anterior, no quiero terminar esta exposición sin volver a reconocer el gran avance experimentado en los últimos años por los tribunales españoles en lo que se refiere a la estimación de la responsabilidad de los $\operatorname{abogados}^{65}$. $\mathrm{Al}$ incremento de sentencias hay que sumar, además, cierto cambio de orientación de la jurisprudencia, que parece inclinar la balanza a favor del cliente. Por ello, coincido con mi maestro, Miquel González en que, a juzgar por el elevado número de sentencias sobre el tema en los últimos tiempos, el ejercicio de la abogacía se está convirtiendo en una profesión peligrosa ${ }^{66}$.

\section{BiBLIOGRAFÍA}

Albanés Membrillo, Antonio, "La responsabilidad civil del abogado: quantum indemnizatorio. Comentario a la STS de 28 de enero de 1998", en revista Otrosínet, Madrid, mayo 1998.

Alonso Pérez, María Teresa, Los contratos de servicios de abogados, médicos y arquitectos, Barcelona, Editorial Bosch, 1997.

p. 311). Sin embargo, en ocasiones, tal confusión puede estar totalmente justificada. Por ejemplo, no resultará fácil, en algunos casos, dibujar la línea divisoria entre la pérdida de la oportunidad y la privación de la pretensión, cuando se trate de pretensiones con altas probabilidades de estimación, pero cuya prosperabilidad no pueda ser asegurada.

${ }^{64}$ Expresión utilizada por la sentencia del Tribunal Supremo de 25 de junio de 1998. De hecho, Alma Rodríguez Guitián, "Indemnización del daño moral derivado del incumplimiento contractual (a propósito de la STS de 31.10.2002)", en Anuario de Derecho Civil, tomo LVI, fascículo II, Madrid, 2003, p. 831, denuncia la utilización indiscriminada por buena parte de los tribunales españoles de esta clase de daños.

${ }^{65}$ Miquel González, José María, "Prólogo", en María Carmen Crespo Mora, La responsabilidad del abogado en el Derecho civil, Navarra, Thomson-Civitas, 2005, p. 27: "He observado como curiosidad que, sobre reclamaciones a los abogados, en una conocida base de datos se contabilizan 410 sentencias entre los años 2000-2004 (Audiencias y Supremo), 68 entre 1995-1999, 9 entre 1990-1994, 1 hasta 1989. Los números son suficientemente expresivos".

${ }^{66}$ MiQuel González (n. 65), p. 27. 
Álvarez Vigaray, Rafael, "La responsabilidad por daño moral", en Anuario de Derecho civil, vol. 19, № 1, Madrid, 1966.

Ángel YÁgüEz, Ricardo de, "Comentario al artículo 1902 CC", en Comentario del Código civil, Sierra Gil de la Cuesta (coord.), Barcelona, Editorial Bosch, 2000, tomo 8 (arts. 1790 al 1902).

Bercovitz Rodríguez-Cano, Rodrigo, "Responsabilidad de abogados y procuradores", en Aranzadi Civil, No 3, Navarra, 1997.

Cancio Melí́, Manuel, "Comentario al capítulo vir CP. De la obstrucción a la justicia y la deslealtad profesional: artículos 463, 465, 466 y 467”, en Gonzalo Rodríguez Mourullo (dir.), Jorge Barreiro (coord.), Comentarios al Código penal, Madrid, Editorial Civitas, 1997.

Castillo Martínez, Carolina del Carmen, "La indemnización por daños y la problemática de su cuantificación (cuestiones escogidas)", en Revista Actualidad Civil, No 41, Madrid, semana del 3 al 5 de noviembre de 2003.

Cavanillas Múgica, Santiago, Isabel TaPia Fernández La concurrencia de responsabilidad contractual y extracontractual. Tratamiento sustantivo y procesal, Madrid, Centro de Estudios Ramón Areces, 1992.

Cervilla Garzón, María Dolores, La prestación de servicios profesionales, Valencia, Editorial Tirant lo Blanch, 2001.

Cervilla Garzón, María Dolores, "Una nueva visión de la responsabilidad profesional del abogado", en Actualidad Civil, N 40, Madrid, semana del 27 de octubre al 2 de noviembre de 2003.

Crespo Mora, María Carmen, "Responsabilidad civil del abogado. Especial referencia a la pérdida de la oportunidad procesal. Comentario a la STS de 29 de mayo de 2003", en Revista de Derecho Patrimonial, No 12, Navarra, 2003.

Crespo Mora, María Carmen, La responsabilidad del abogado en el Derecho civil, Navarra, Ed. Thomson-Civitas, 2005.

Chartier, Yves, La réparation du préjudice, Paris, Ed. Dalloz, 1996.

De FAzio, Francesco, "Responsabilitá del legale e perdita della chance di vincere il proceso", in Responsabilitá Civile e Previdenza, vol. 62, settembre-dicembre 1997.

Dízz-Picazo, Luis, Derecho de daños, Madrid, Editorial Civitas, 2000.

Gómez pomar, Fernando, "Pleitos tengas: pérdida de un litigio, responsabilidad del abogado y daño moral. Comentario a la STS de 8 de abril de 2003", en www.indret.com, julio 2003.

GonzÁlez-FERrer, J. y J. YbarRa LÓPEZ-Gómez, "La indefensión ocasionada por error del abogado", en Otrosínet, No 37, Madrid, mayo 2002.

IlLeSCAS Rus, Ángel V., "El daño moral estricto", en VV.AA., Valoración judicial de los daños y perjuicios, Madrid, Consejo General Poder Judicial, 1999.

Larroumet, Christian, Droit civil, Les obligations, $6^{\mathrm{a}}$ ed., Paris, Economica, 2007, tomo III, seconde partie.

Martínez Calcerrada y Gómez, Luis, "La responsabilidad civil profesional del abogado", en Luis Martínez-CALCERRAda y Gómez, La responsabilidad civil 
profesional de los teleinformáticos, auditores de cuentas, periodistas, arquitectos-peritos, médicos-peritos y de los peritos judiciales en general. Especial estudio de la responsabilidad civil de los médicos, administradores, consejeros de las sociedades mercantiles y de los abogados, Madrid, Editorial Colex, 1991.

Mazeaud, Henry - André Tunc, Tratado teórico y práctico de responsabilidad civil delictual y contractual, traducción de la quinta edición por Niceto Alcalá-Zamora y Castillo, Buenos Aires, Ediciones Jurídicas Europa-América, 1961-1963, tomo I, vol. I.

Miquel GonzÁLEz, José María, "La responsabilidad contractual y extracontractual: distinción y consecuencias", en Responsabilidad Civil, Cuadernos de Derecho Judicial, No 19, Madrid, 1993.

Miouel González, José María, "Prólogo", en María Carmen Crespo Mora, La responsabilidad del abogado en el Derecho civil, Navarra, Thomson-Civitas, 2005.

MülLER, Christoph, "Schadenersatz für verlorene Chancen. Ei des Kolumbus oder Trojanisches Pferd?", in www.wenger-plattner.ch.

Pantaleón Prieto, Fernando, "Comentario al artículo 1902 CC", en Comentarios del Código civil, Madrid, Ministerio de Justicia-Editorial Civitas, 1993, tomo II.

Parra LucÁn, María Ángeles y Luis Fernando Reglero Campos, "La responsabilidad civil de los profesionales del Derecho", en Luis Fernando REglero CAmpos (coord.), Tratado de responsabilidad civil, $4^{\text {a }}$ ed., Navarra, Ed. ThomsonAranzadi, 2008, tomo II.

Peano, Marie-Annick, "Avocat", en Juris-Classeur civil, No 32, fasc. 330, arts. 1382 à 1386, Quebec, s/a.

Rodríguez Guitián, Alma, La muerte del oferente como causa de extinción de la oferta contractual, Madrid, Editorial. Civitas, 2003.

Rodríguez Guitián, Alma, "Indemnización del daño moral derivado del incumplimiento contractual (a propósito de la STS de 31.10.2002)", en Anuario de Derecho Civil, tomo LVI, fascículo II, Madrid, 2003.

Serra Rodríguez, Adela, La responsabilidad civil del abogado, Navarra, Edtorial Aranzadi, 2001.

Vicente Domingo, Elena, "El daño", en Tratado de responsabilidad civil, Luis Fernando Reglero Campos (coord.), $4^{\text {a }}$ ed., Navarra, Editorial Thomson-Aranzadi, 2008, tomo I: Parte general.

YzQuierdo Tolsada, Mariano, "Responsabilidad civil del abogado", en La Universidad y las profesiones jurídicas (Deontología, función social y responsabilidad), ciclo de conferencias, Madrid, Universidad Complutense de Madrid, Consejo Social, 1998.

YzQuierdo Tolsada, Mariano, "Comentario a la STS de 10 de octubre de 1998”, en Cuadernos Civitas de Jurisprudencia Civil, No 50, Navarra, abril-agosto 1999.

Yzquierdo Tolsada, Mariano, "Comentario a la STS de 28 de enero de 1998", en Cuadernos Civitas de Jurisprudencia Civil, $\mathrm{N}^{\circ}$ 47, Madrid, abril-agosto 1998. 
YzQuierdo Tolsada, Mariano, Sistema de responsabilidad civil, contractual y extracontractual, Madrid, Editorial Dykinson, 2001.

SENTENCIAS Citadas

(CON REFERENCIA DE Westlaw España)

Sentencias del Tribunal Constitucional

STC de 7 de febrero de 1984 (RTC, 1984, 18)

Sentencias del Tribunal Supremo

STS de 4 de febrero de 1950 (RJ, 1950, 191)

STS de 9 de marzo de 1983 (RJ, 1983, 1463)

STS de 10 de mayo de 1984 (RJ, 1984, 2405)

STS de 28 de noviembre de 1984 ( $R J, 1984,5688)$

STS de 9 de enero de 1985 (RJ, 1985, 167)

STS de 26 de septiembre de 1989 (RJ, 1989, 6379)

STS de 20 de octubre de 1989

STS de 7 de diciembre de 1989 (RJ, 1989, 8806)

STS de 6 de marzo de 1990

STS de 5 de abril de 1990

STS de 10 de junio de 1991 (RJ, 1991, 4434)

STS de 4 de febrero de 1992 (RJ, 1992, 819)

STS de 23 de diciembre de 1992 (RJ, 1992, 10715)

STS de 23 de octubre de 1995 (RJ, 1995, 7649)

STS de 17 de noviembre de 1995 ( $R J, 1995,8733)$

STS de 20 de mayo de 1996 (RJ, 1996, 3793)

STS de 16 de diciembre de 1996

STS de 11 de noviembre de 1997 (RJ, 1997, 7871)

STS de 28 de enero de 1998 (RJ, 1998, 357)

STS de 25 de marzo de 1998 (RJ, 1998, 1651)

STS de 25 de junio de 1998 (RJ, 1998, 5013)

STS de 3 de octubre de 1998 (RJ, 1998, 8587)

STS de 10 de octubre de 1998 (RJ, 1998, 8371)

STS de 26 de enero de 1999 (RJ, 1999, 323)

STS de 13 de mayo de 1999 (RJ, 1999, 6148) (sala de lo contencioso-administrativo)

STS de 14 de mayo de 1999 (RJ, 1999, 3106) 
STS de 29 de mayo de 1999

STS de 8 de febrero de 2000 (RJ, 2000, 842)

STS de 21 de febrero de 2000

STS de 8 de junio de 2000 (RJ, 2000, 5098)

STS de 18 de marzo de 2001

STS de 21 de mayo de 2001

STS de 23 de mayo de 2001 (RJ, 2001, 3372)

STS de 16 de diciembre de 2001 (sala de lo penal)

STS de 5 de febrero de 2002 (sala de lo penal)

STS de 13 de mayo de 2002

STS de 22 de mayo de 2002 (RJ, 2002, 7562) (sala de lo penal)

STS de 27 de febrero de 2003

STS de 7 de abril de 2003 (RJ, 2003, 3003)

STS de 29 de mayo de 2003 (RJ, 2003, 3914)

STS de 8 de julio de 2003 (RJ, 2003, 4613)

STS de 14 de julio de 2003 (RJ, 2003, 4630)

STS de 28 de julio de 2003 ( $R J, 2003,5989)$

STS de 2 de diciembre de 2003

132 STS de 12 de diciembre de 2003 (diario La Ley, 3 de febrero de 2004, pp. 4-8)

STS de 30 de diciembre de 2003

STS de 10 de febrero de 2004

STS de 12 de marzo de 2004

STS de 18 de junio de 2004 (RJ, 2004, 3629)

STS de 9 de julio de 2004 (RJ, 2004, 5121)

STS de 4 de octubre de 2004

STS de 29 de noviembre de 2004

STS de 18 de febrero de 2005 (RJ, 2005, 1682)

STS de 14 de julio de 2005 ( $R J, 2005,6532)$

STS de 14 de diciembre de 2005 (RJ, 2006, 1225)

STS de 11 de mayo de 2006 (RJ, 2006, 3950)

STS de 23 de mayo de 2006 (RJ, 2006, 5827)

STS de 27 de julio de 2006 (RJ, 2006, 6548)

STS de 23 de marzo de 2007 (RJ, 2007, 1542)

STS de 24 de mayo de 2007 (RJ, 2007, 3124)

STS de 21 de junio de 2007 (RJ, 2007, 3781)

STS de 30 de julio de 2007 (RJ, 2007, 4962)

STS de 15 de noviembre de 2007 (RJ, 2008, 17) 
Sentencias de los Tribunales Superiores de Justicia

STSJ Navarra de 9 de diciembre de 1997 (RJ, 1997, 9414)

Sentencias de las AUdiencias PROVInCIALES

SAP Álava de 15 de septiembre de 1992 (AC, 1992, 1181)

SAP Huesca de 4 de diciembre de 1993 (AC, 1993, 2373)

SAP Guipúzcoa de 12 de septiembre de 1994 (AC, 1994, 1905)

SAP León de 16 de diciembre de 1994

SAP Badajoz de 3 de septiembre de 1996 (AC, 1996, 1469)

SAP Valencia de 23 de abril de 1998 (AC, 1998, 488)

SAP Asturias de 6 de mayo de 1998

SAP Castellón de 9 de septiembre de 1998 (AC, 1998, 1715)

SAP Cáceres de 7 de abril de 2000

SAP Málaga de 25 de abril de 2002 (JUR, 2002, 197437)

SAP Barcelona de 26 de junio de 2002 (AC, 2002, 2313)

SAP Valencia de 1 de julio de 2002

SAP Castellón de 18 de noviembre de 2002 (ARP, 2002, 716) (jurisdicción penal)

SAP Vizcaya de 20 de diciembre de 2002 (JUR, 2002, 133328) (jurisdicción penal)

SAP Cantabria de 11 de febrero de 2003 (JUR, 2003, 148479)

SAP Castellón de 18 de julio de 2003

SAP Toledo de 19 de enero de $2004(A C, 2004,9)$

SAP Las palmas de 9 de marzo de 2004 (JUR, 2004, 134110)

SAP Toledo de 27 de diciembre de 2007 (ARP, 2008, 134) 